$\left(\begin{array}{llrr}\text { Jjn. } & \text { J. } & \text { Hosp. } & \text { Pharm. } \\ 22(1) & 89-94 & (1996)\end{array}\right)$

水晶発振子を用いたポリマーによる有機リン系殺虫剤および除草剤の吸着

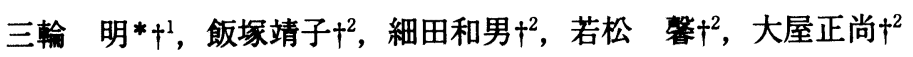

日高病院薬郕部 $\dagger^{1}$

群馬大学工学部生物化学工学科 $\dagger^{2}$

\title{
Application of Quartz-Crystal Microbalance for Detection of Adsorption Capacity of Agricultural Chemicals on Polymers
}

\author{
AKIRA MIWA ${ }^{*} \dagger^{1}$, YASUKO IIZUKA $\dagger^{2}$, KAZUO HOSODA $\dagger^{2}$, \\ KAORI WAKAMATSU $\dagger^{2}$ and MASANAO OYA $\dagger^{2}$ \\ Department of Pharmacy, Hidaka Hospital $\dagger^{1}$ \\ Department of Biological Science, Faculty of Engineering, Gunma University $\dagger^{2}$ \\ $\left(\begin{array}{l}\text { Received June 20, } 1995 \\ \text { Accepted November 6, 1995 }\end{array}\right)$
}

We analysed the adsorption of organic phosphorous insecticides and herbicides by ethylcellulose, acetylcellulose, polysulfone, polystyrene and polyvinylchloride using the quartz-crystal microbalance (QCM). Ethylcellulose had a high affinity for both organic phosphorous insecticides and herbicides. The adsorption capacity of acetylcellulos exhabited a low adsorption except for cyanophos.

Polysulfone and polystyrene featured a high affinity for organic phosphorous insecticides and herbicides which polyvinylchloride had low except for fenitrothion. These results indicate that adsorption of insecticides and herbicide by polymers is affected by the chemical structure of the polymers used.

Key words - quartz-crystal microbalance, polymer, adsorption, organic phosphorous insecticides, herbicide

$\dagger^{1}$ 群馬県高崎市中尾町886;886, Nakao-machi, Takasaki-shi, Gunma, 370 Japan

$\dagger^{2}$ 群馬県桐生市天神町 $1-5-1 ; 1-5-1$, Tenjin-cho, Kiryu-shi, Gunma, 376 Japan

\section{緒 \\ 言}

農薬は農産物の飛躍的増産に貢献している反面, 誤飲事故等の問題が絶えない。これら農薬中毒の 初期治療に用いるため有効な吸着剂の開発が必要 とされている. 
我々はすでに，ポリアミノ酸が有機リン系殺虫 片や除草剤をよく吸収することを報告した ${ }^{1,2)}$. またng単位で定量できる微少量天秤 quartzcrystal microbalance (QCM) の方法 ${ }^{3-5)}$ を用いて 農薬の吸着量を求めるとともに, 吸着平衡に達す るまでの時間を測定できることも明らかにした ${ }^{6)}$. 今回は, ポリアミノ酸以外のポリマーでも農薬 を吸着できる物質があるのではないかと考え，い くつかのポリマーについて QCM の方法を用い農 薬の吸着量を測定した。使用したポリマーは，既 報 ${ }^{1,2)}$ においてよく農薬を吸着したエチルセルロ 一ス，類似した化学構造を持つ酢酸セルロース， また既報においては農薬を吸着しなかったポリス チレンとポリ塩化ビニル，そしてポリスルホンを 用いた. 図 1 にポリマーの化学構造式を示す.

農薬としては中毒症例の多い7), 有機リン系殺 虫剂と疎水性の除草剂を用いた。有機リン系殺虫 剤としては中毒症例が多いフェニトロチオン，ま たフェニトロチオンと化学構造が類似しているシ アノホス，イソキサチオンを用いた。また除草剤 としては, その化学構造にベンゼン環を持つジニ トロアニリン系化合物のトリフルラリンを用いた。

$$
\begin{gathered}
-\left[\mathrm{C}_{6} \mathrm{H}_{7} \mathrm{O}_{2}(\mathrm{OH})_{3}-{ }_{\mathrm{m}}\left(\mathrm{OC}_{2} \mathrm{H}_{5}\right)_{\mathrm{m}}\right]_{\mathrm{n}}- \\
\text { エチルセルロース }
\end{gathered}
$$

\section{実殹方法}

\section{1. 試料}

1) 農薬

フェニトロチオン (0,0-Dimethyl 0-4-nitrom-tolyl phosphorothioate: スミチオン乳剤, 八州 化学工業(侏)，イソキサチオン (0,0-diethyl 0( 5 -phenyl 1-3-isoxazolyl)phosphorothioate:カル ホス乳剤, 三共(侏))，シアノホス（0-4-cyanophenyl 0,0-dimethylphosphorothioate:サイア ノックス乳剤, 三共(侏)), トリフルラリン $(\alpha, \alpha$, $\alpha$-trifluoro- 2,6 - dinitro $\mathrm{N}, \mathrm{N}$-dipropyl- $\rho$-toluidine :トレファノサイド乳剤，塩野義製薬(侏)）を用 いた。

2 ) 吸着剂

吸着剤としてエチルセルロース（50cps，エチ ル化度 $50 \%$, 半井化学(侏)，酶酸セルロース（岩 井化学薬品(侏), ポリ塩化ビニル (重合度 800 , 和 光純薬(侏), ポリスチレン, ポリスルホンを用いた. これらはいずれも市販品である.

\section{2. 実験}

1 ) 測定装置

水晶発振子は, AT-cut, 基本共鳴周波数 9 [MHz]（九州電通(侏)）のものを用い，これを恒 温槽で温度コントロールされた各測定環境におい た. 発振子は直流安定装置安定電源装置（model

$-\left[\mathrm{C}_{6} \mathrm{H}_{7} \mathrm{O}_{2}(\mathrm{OH})_{3}-\mathrm{m}\left(\mathrm{OCOCH}_{3}\right)_{\mathrm{m}}\right]_{\mathrm{n}}-$ 酢酸セルロース

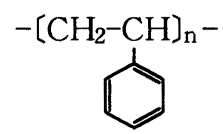

ポリスチレン

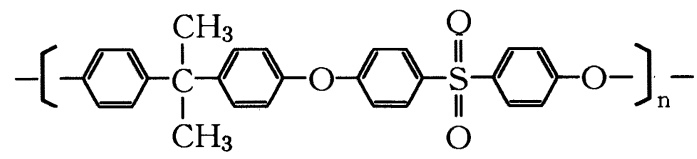

ポリスルホン

図 1.ポリマーの化学構造式 
GPR-1810, Good will instrument Co.) で直流電流 $5[\mathrm{~V}]$ で駆動した. 発振子の共鳴周波数は, 共振回路 と同軸ケーブルで接続してある周波数測定装置 (model SC-7201, 岩通(侏)) で測定し, GP-IB インターフェイスボード (model PC-9801-29m, NEC）で接続したパーソナルコンピューター (model PC-9801Vm, NEC) に取り込んだ。

2 ) 測定方法

エチルセルロース, ポリスチレン，ポリスルホ ンはジクロロメタンに, 酢酸セルロースとポリ塩 化ビニルはテトラヒドロフランに $1 \mathrm{mg} / \mathrm{ml}$ 濃度 に溶かした。

電極上に何ものせていない水晶発振子の周波数 （F０）を測定し，次に溶かしたポリアミノ酸を シリンジで水晶発振子の電極上にのせ溶媒を完全 に飛ばした。このとき膜の重量が重すぎると農薬 を吸着した際，電極からはがれやすくなり測定が 不能となるので, 周波数 (F1) を測定しながら
調節した．周波数の $1[\mathrm{~Hz}]$ の変化が電極上の質量 変化約 $1 \mathrm{ng}$ に対応しているので, (F0) から

（F1）を引いたものが，ポリマーの膜量に対応 する. $37^{\circ} \mathrm{C}$ の恒温槽で温度コントロールされた容 器（容量 $14 \mathrm{ml}$ ) に蒸留水を約 $13 \mathrm{ml}$ 入れておき, ポリアミノ酸の膜が付いた水晶発振子を容器内に 入れた. 周波数が平衡状態に達した時点での周波 数（F 2) を測定した。

次に農薬を加え $1 \mu \mathrm{M}$ 濃度にしたとき，ポリマ 一が農薬を吸着すると周波数は隇少した，再び平 衡状態に達した時点での周波数（F3）を測定し た（F 2）と（F3）の差が農薬の吸着量に対応 する。（F0）と（F1）の周波数の差に対する (F 2$)$ と（F3）の周波数の差の割合を吸着率 （\%）として表わした. また，周波数は 1 秒ごと に測定できるので，農薬の吸着平衡に達するまで の時間を測定した。

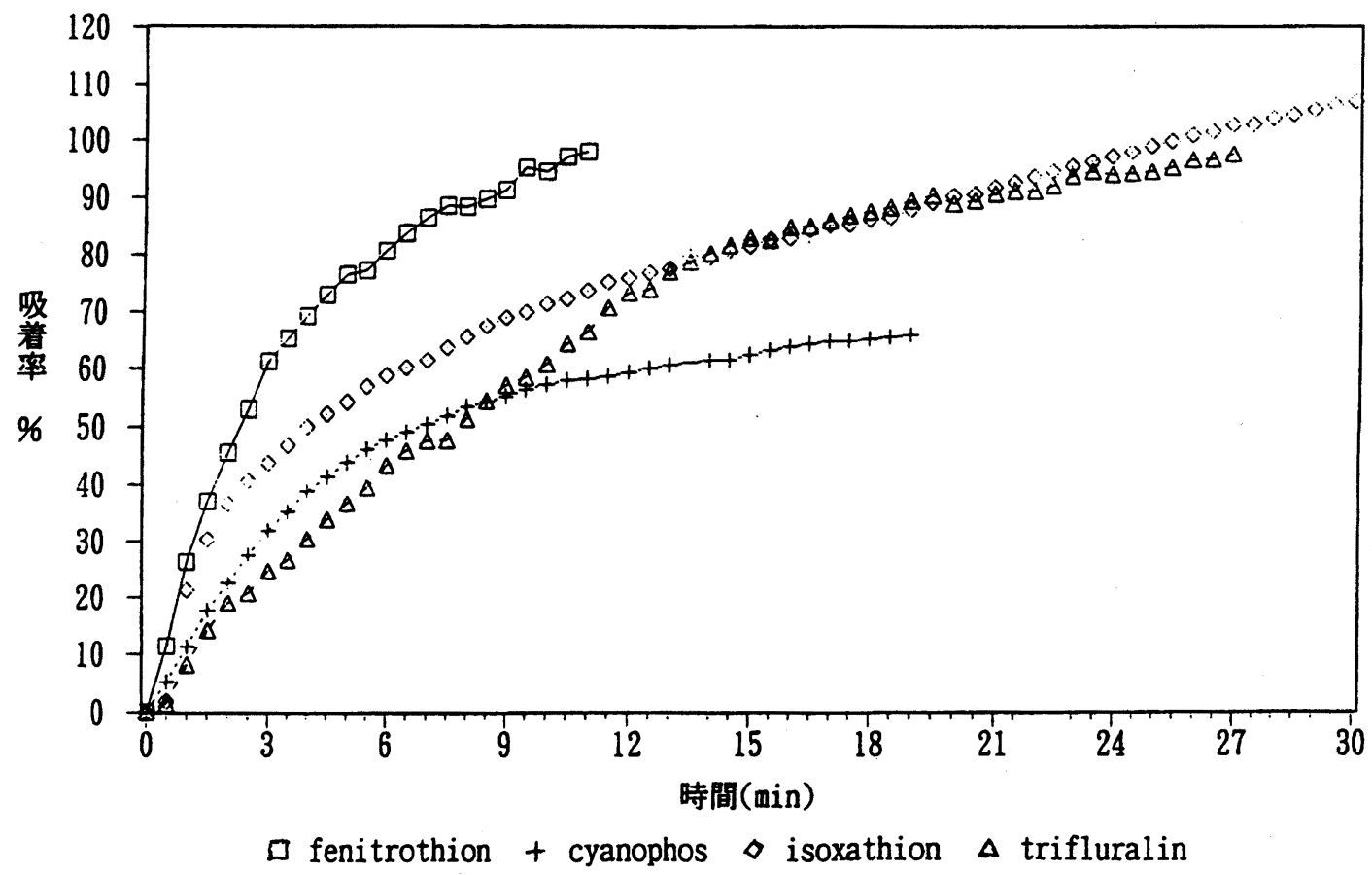

図 2.エチルセルロースによる農薬の吸着率の経時変化

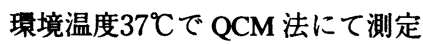




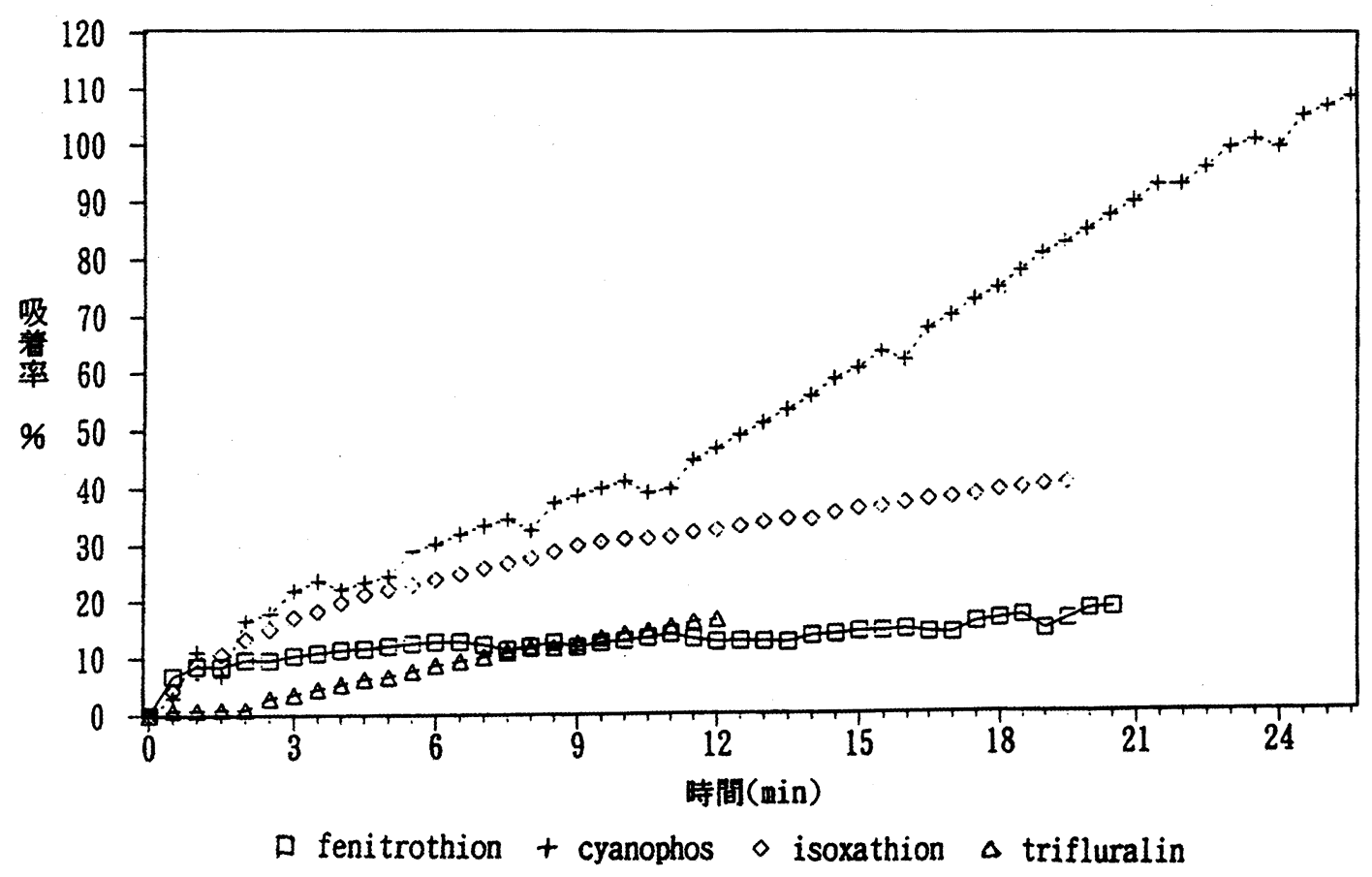

図 3.酢酸セルロースによる農薬の吸着率の経時変化

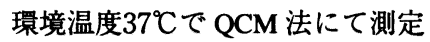

\section{結果および考察}

エチルセルロースによる農薬吸着率の経時変化 を図 2 に示した。エチルセルロースはいずれの農 薬においても高い吸着率を示した，特にフェニト ロチオン, イソキサチオン, トリフルラリンでは, エチルセルロース自身の質量と同じくらい, 農薬 が吸着した。

酢酸セルロースによる農薬吸着率の経時変化を 図3に示した。酢酸セルロースによるシアノホス の吸着では, 酢酸セルロースの質量以上シアノホ スは吸着した。しかしイソキサチオンは酢酸セル ロースの質量の $40 \%$ 吸着はしたものの, フェニト ロチオンやトリフルラリンの吸着率は低かった。

既報 ${ }^{1)}$ では, ポリマー $10 \mathrm{mg}$ を0.5M 濃度のフ エニトロチオン $10 \mathrm{ml}$ を $37^{\circ} \mathrm{C} て ゙ 2$ 時間吸着させた。 その結果, エチルセルロースはフェニトロチオン をよく吸着した。既報 2 におおてはポリマーに
よる高濃度農薬の吸着について報告した。この際 エチルセルロースは非常によく農薬を吸着した。 エチルセルロースは農薬との親和性が強いものと 考えられ，エチルセルロースの方が酢酸セルロー スと比べ農薬の吸着率も高く, 平衡吸着に達する 時間も早かったものと思われる.エチルセルロー スと酢酸セルロースの化学構造上の差異は, 官能 基が異なるだけであるが，農薬の吸着にこれだけ の差異を生じたことは與味深い.

各ポリマーによる平衡吸着に達した農薬の吸着 率の比較を図 4 に示した。また各ポリマーによる 農薬の吸着平衡時間（分）も図4に列記した。

これらのポリマーでは, エチルセルロースによ る農薬の吸着率が全体的に高かった。ポリスチレ ンによるトリフルラリンの吸着率は低かったが, シアノホス, イソキサチオンの吸着率は高かった。 特にイソキサチオンの吸着においては, ポリスチ レンの質量と同じくらい農薬を吸着した。またフ 


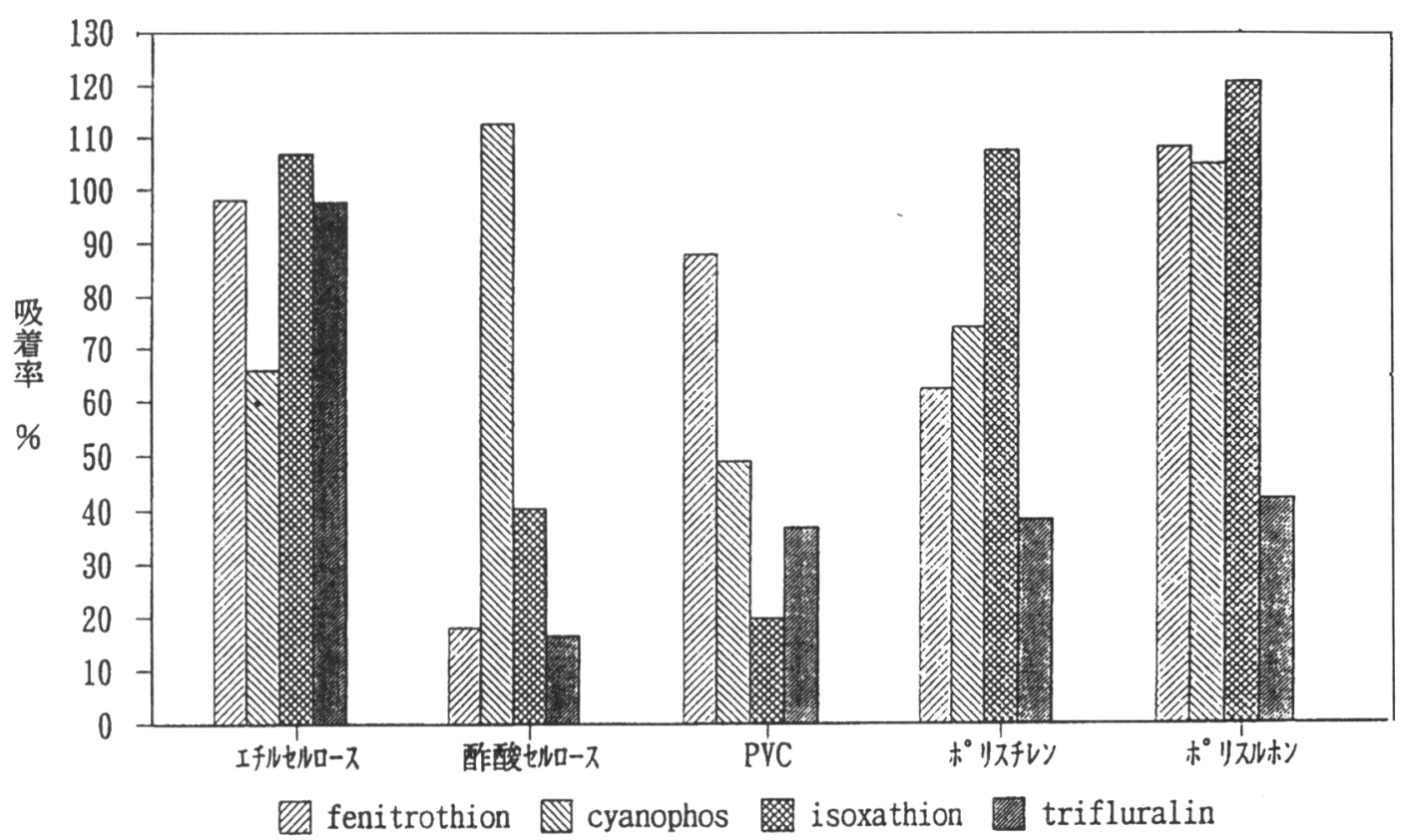

図 4.各ポリマーによる農薬の吸着率

各ポリマーによる農薬吸着平衡時間（分）

\begin{tabular}{lcccc}
\hline & フェニトロチオン & シアノホス & イソキサチオン & トリフルラリン \\
\hline エチルセルロース & 9 & 18 & 16 & 15 \\
酢酸セルロース & 2 & 28 & 20 & 12 \\
PVC & 12 & 18 & 11 & 10 \\
ポリスチレン & 35 & 18 & 25 & 10 \\
ポリスルホン & 26 & 30 & 37 & 12 \\
\hline
\end{tabular}

エニトロチオンの吸着では, 吸着率は高いものの, 吸着平衡に達するまでの時間は長かった。

ポリ塩化ビニルはフェニトロチオンをよく吸着 した。しかし，イソキサチオンやトリフルラリン はあまり吸着しなかった。また，シアノホスの吸 着では, 初期の吸着率はトリフルラリンよりも少 なかったが，最終的にはポリ塩化ビニルの質量の 50\%吸着した。ポリスルホンによるフェニトロチ オン, シアノホス, イソキサチオンの吸着では, ポリスルホンの質量以上に吸着した。またトリフ ルラリンの吸着率は他の農薬と比べると低かった が, ポリスルホンの質量の $42 \%$ 吸着した。

ポリスチレンやポリスルホンはその化学構造に
ベンゼン環を有する。そのため分子が大きく，農 薬を吸着する面が広いため, 農薬の吸着率が高か ったためと考えられる。しかし既報”において， 粉末状で用いたポリスチレンやポリ塩化ビニルは あまり農薬を吸着しなかった。これはポリマーの 立体構造に起因するためと考えられる。

被吸着質が吸着剤に吸着されるまでの過程は三 つの段階に分けて考えられている。（1）被吸着 質の液境膜中への拡散, (2) 被吸着質の吸着細 孔内への拡散, (3) 吸着剂表面への吸着であ る ${ }^{8)}$. ポリスチレンやポリ塩化ビニルなど粉末 状にしたポリマーは, 細孔が発達してないためあ まり農薬を吸着しなかったのではないかと考えら 
れる。

QCM 用いた方法では, 吸着剤を薄膜にして 用いている。 そのためポリマーによる農薬の吸着 においては, ポリマーの化学的な性質に由来し, ポリマーを粉末状として用いた場合よりもその立 体構造による影響は少ない。そのため粉末状のポ リマーで農薬をあまり吸着しなかったのにもかか わらず，QCMを用いた方法で農薬の吸着率が高 かったのは, 農薬が直接ポリマーの薄膜に吸着す るからであると考えられる.

またポリスチレンやポリスルホンではトリフル ラリンはあまり吸着せず, ポリ塩化ビニルではフ エニトロチオンはよく吸着した，その他の農薬は あまり吸着しなかった.このように農薬の種類に より吸着率に差が生じた.このことから, ポリマ 一による農薬の吸着においては, その化学構造が 農薬の吸着に影響を与えていると考えられる。

以上のようにポリアミノ酸だけでなく，他のポ リマーにおいても農薬を効率よく吸着することが 明らかになった。これらのポリマーは成型しやす く,その応用は広い. 今後ポリマーを吸着剤とし て応用するためには，フィルム加工として使用す る場合，あるいは粉末として使用する場合でも，
農薬を吸着しやすいような細孔を持つ粒子にする など工夫する必要がある。

謝辞 本研究において, 御教示いただいた東京工業 大学の岡畑恵雄教授ならびに群馬大学の飯塚靖子技官 に感謝いたします。

\section{引用文献}

1）三輪 明，飯塚靖子，若松 馨，大屋正尚，日 本農芸化学会誌, 66, 1467-1473（1992）。

2 ）大屋正尚, 三輪 明, 飯塚靖子, 若松 馨, 日 本農芸化学会誌, 69, 671-677 (1995).

3 ) Yoshio Okahata and Katsuhiko Ariga, J. Chem. Soc., Chem. Commun., 1535-1537 (1987).

4) Yoshio Okahata, Kazuhiko Kimura and Katsuhiko Ariga, J. Am. Chem. Soc., 111, 9190-9194 (1989).

5 ) D. A. Buttry and M. D. Ward, Chem. Rev., 92, 1355-1379 (1992).

6）三輪 明, 夏目陽介, 飯塚靖子, 若松 馨, 大 屋正尚, 病院薬学, 21, 347-351 (1995).

7 ）財)日本中毒情報センター, 中毒研究, 6, 415418 (1993).

8 ）柳井 弘, “吸着郕 - 吸着操作の設計”, 技報堂 出版, 東京, 1982, pp. 148-170. 